\title{
Gentrificação no Bairro 2 de Julho, em Salvador: modos, formas e conteúdos
}

\author{
Gentrification in the neighborhood 2 de Julho, \\ in Salvador: modes, forms and contents
}

Glória Cecília Figueiredo

Nelson Baltrusis

\section{Resumo}

Este artigo tem como objetivo entender os processos recentes de reestruturação urbana que vêm tomando corpo no centro antigo de Salvador, mais particularmente, as ações corporativas e públicas apoiadas na lógica da gentrificação e da privatização do espaço urbano. Para tanto, concentramos a presente análise na proposta de intervenção no Bairro 2 de Julho, buscando entender como esse processo vem se constituindo nesta área reconhecida pela Unesco como Patrimônio da Humanidade. Nos empreendimentos privados apoiados pelo poder público, evidencia-se processos de exclusão social, produzidos por um modelo de planejamento urbano excludente pautado na concepção do urbanismo corporativo, que se utiliza de mecanismos de desvalorização e revalorização de patrimônio histórico-cultural. Contribuindo assim, para facilitar e ampliar o processo de ressignificação do patrimônio urbano e a expulsão da população mais pobre.

Palavras-chave: centro antigo de Salvador; gentrificação; Bairro 2 de Julho; Patrimônio da Humanidade; privatização do espaço.

\begin{abstract}
The purpose of this article is to understand the recent urban restructuring processes that have taken shape in the historic center of Salvador, particularly the corporate and governmental actions supported by the logic of gentrification and privatization of the urban space. The analysis focuses on the proposal for intervention in the Neighborhood 2 de Julho, in order to understand how this process has taken place in this area, which has been recognized by Unesco as a World Heritage site. In the private developments supported by the government, social exclusion processes are evident. They are produced by an exclusionary model of urban planning based on a conception of corporate urbanism that uses mechanisms of devaluation and revaluation of the historic-cultural heritage. This contributes to facilitate and expand the process of resignification of the urban heritage and the expulsion of the poor population.
\end{abstract}

Keywords: historic center of Salvador, gentrification; Neighborhood 2 de Julho; World Heritage site; privatization of urban space. 


\section{Introdução}

Desde o início da década de 1970, o centro antigo da cidade de Salvador tem sido marcado por intervenções que atuaram no sentido de fragmentar, esconder ou afastar os moradores pobres de seu território. Territórios esses que foram apropriados, ao longo do tempo, pela população pobre e onde se sobrepuseram seu modo de vida em relação ao ambiente construído (Mourad e Baltrusis, 2012, p. 762). Essas intervenções foram pensadas e executadas de acordo com um tipo de urbanismo excludente, que privilegia as intervenções-cenários voltadas ao turismo, em contraposição à manutenção dos moradores tradicionais. De acordo com Arantes, essa lógica destaca que o uso da imagem e da cultura tem sido um elemento central nos projetos de renovação que se utilizam de uma arquitetura-espetáculo para recriar cenários (2000).

Ana Fernandes, referindo-se aos desdobramentos urbanos advindos da criação do centro Iguatemi, na década de 1970, constata a instauração de uma crise de centralidade. Ela nota

[...] ao lado da desaceleração do processo de reprodução do centro tradicional, a produção ampliada de áreas degradadas, vazias e mesmo em ruínas, aliada a preços fundiários e imobiliários depreciados, estrutura de propriedade difícil de ser reconstituída, patrimônio histórico, artístico e cultural de primeira grandeza e ocupação e uso por segmentos populacionais sobretudo de renda média e baixa. (Fernandes, Mourad e Silva, no prelo)

\section{Fernandes observa que}

Diversas iniciativas governamentais se sucedem no tempo, buscando construir alternativas de desenvolvimento para o centro antigo, em particular aquele que vem a ser chamado Centro Histórico de Salvador. Dos anos 1990 em diante, período que marca a contemporaneidade das ações, as alternativas concebidas se ancoram numa visão de patrimônio histórico, cultural e turístico e, mais recentemente, a ela se agregam, numa perspectiva mais complexa - e contraditória -, as de patrimônio social, urbano e imobiliário. (Ibid.)

Este texto procura entender os processos recentes de reestruturação urbana que vêm tomando corpo no centro antigo de Salvador, mais particularmente as ações corporativas e públicas apoiadas na lógica da produção da gentrificação e na privatização do espaço urbano, tomando o Bairro 2 de Julho como objeto de análise.

Inicialmente é feita uma breve revisão teórica sobre o conceito de gentrificação. Numa segunda parte analisamos como esse conceito é utilizado no projeto Cluster Santa Tereza, capitaneado pelas empresas Eurofort Patrimonial e a RFM Participações, mas que conta com a atuação da Prefeitura Municipal de Salvador através do "Projeto de Renovação do Bairro Santa Tereza", atinente à mesma área do cluster.

Apresentamos ainda os instrumentos urbanísticos propostos pelo Governo do Estado da Bahia, através do Escritório de Referência do Centro Antigo de Salvador (Ercas), que reforçam a atuação gentrificadora no Bairro 2 de Julho. 
Também é tratado o movimento de contraposição aos processos de gentrificação. Aborda-se ainda a estratégia de monetização do patrimônio histórico e cultural, operada pela empresa Brazil Hospitality Group - BHG no bairro. Por fim, são feitas algumas considerações sobre os processos analisados.

\section{Gentrificação como mecanismo altamente rentável}

Vários autores, como Arantes (2000), Maricato (2002), Rolnik (2006), Silva (2006), Fernandes (2006), José (2007), Vainer (2002), Mourad (2011) entre outros, alertam que no Brasil, sobretudo nas grandes cidades, a requalificação em áreas centrais tem sido caracterizada por processos de gentrificação, marcados pela atração de novos tipos de atividades e de novos moradores, reinvestimento econômico, mudança de significado e imagem, melhoria ambiental e "limpeza social", ou seja, a expulsão dos moradores pobres das áreas de intervenção. Para Menna Barreto, esse processo "mistura motivações e propostas diversas, que incluem o repovoamento e, mais recentemente, os projetos integrados que aproveitam grandes terrenos públicos junto às orlas marítimas ou fluviais" (Silva, 2006, p. 13).

Para Fernandes

[diversas] dessas experiências têm sido profundamente marcadas por uma lógica neoliberal, guiadas pelos princípios do planejamento estratégico e da competição entre cidades no mercado internacional. Em geral, essa política se ancora na execução ou na tentativa de implementação de programas e projetos fundados na reconquista de áreas restritas dos centros pelo capital corporativo e especulativo, pela gentrificação social e pela construção de horizontes simbólicos banalizados e midiáticos. A eles, com força crescente, sobrepõem-se estratégias vinculadas ao turismo, que instaura um excitado e voraz consumo da urbanidade, simétrico à velocidade dos tempos de consumo que podem ser dedicados pelo turista, que deixou de ser aprendiz, a cada cidade. $(2008$, p. 31$)$

Para Hamnett (1996, p. 61), gentrificação é um fenômeno físico, econômico, social ou cultural. A gentrificação incide não apenas em uma transformação social, mas também em uma alteração física do estoque de moradias, na escala de bairros, representando, enfim, uma transformação econômica sobre os mercados fundiários e imobiliários. É essa combinação de mudanças sociais, físicas e econômicas que distingue a gentrificação como processo ou conjunto de processos específicos. ${ }^{1}$

Segundo este autor, gentrificação caracteriza-se como

[...] um processo de transformação da composição social dos residentes de um bairro, mais precisamente da substituição de camadas populares por camadas médias assalariadas; e se constitui em um processo de natureza múltipla: de investimento, de reabilitação e de apropriação, por essas camadas sociais, de um estoque de moradias e de bairros operários ou populares. (Ibid., p. 55) ${ }^{2}$

0 termo gentrificação foi utilizado pela primeira vez por Glass, ${ }^{3}$ nos anos de 1950, para explicar as transformações de antigos bairros populares e desvalorizados no centro 
de Londres. Esse conceito alcançou forte capacidade explicativa a partir dos trabalhos de Neil Smith, que reconhece três ondas sobre os processos de gentrificação: a primeira seria esporádica e se limitaria a nichos estritos do mercado. A segunda marcaria a consolidação do processo, provocando transformações sociais numa rede muito mais ampla de reestruturação urbana (Smith, 2001, p. 63; 2006, p. 19). De acordo com Otilia Arantes,

A terceira redundaria na criação de um conjunto de serviços e equipamentos-isca para toda uma população de classe média e média-alta disposta a consumir. É quando Neil Smith recorre ao termo "generalizada": puxada em geral pelo Estado, muitas vezes dissimulando o processo com a alegação de um renewal de toda uma região, em parceria com o setor privado, que não apenas se concentraria na valorização dos centros urbanos ou só na melhoria das habitações, mas abrangeria a criação de um número grande de atrações (restaurantes, equipamentos esportivos, etc., sem esquecer os culturais, obviamente) que possam trazer toda uma população com um novo perfil, que não só aí circule, mas que, dadas as vantagens oferecidas, venha a se instalar nestes novos enclaves. ${ }^{4}$

A compreensão do fenômeno de gentrificação nos leva à necessidade de explicar as transformações da oferta da propriedade gentrificável e das práticas dos produtores do espaço urbano, por meio do estudo dos atores econômicos, das instâncias financeiras e das instituições políticas. Para Smith, a interpretação desse fenômeno exige uma análise do processo histórico de desvalorização do capital no centro da cidade. Para isso, propôs o modelo explicativo do rent gap ou do diferencial de renda, apoiando-se na análise dos dados de desinvestimento e de reinvestimento no ambiente construído: num primeiro momento, ocorre a fuga de capitais para a periferia, provocando uma degradação dos imóveis nos centros das cidades, a ausência de manutenção e um crescimento de habitações vazias (Smith, 1979, p. 546).

De acordo com Smith (1979, p. 546)

[...] a gentrificação ocorre quando a depreciação dos imóveis é significativa, quando o gap (o diferencial de renda) é suficientemente amplo para que empreendedores possam adquirir estruturas muito baratas, possam pagar os custos de construir e lucrar com a reabilitação, possam também pagar os juros sobre os empréstimos pessoais e sobre os empréstimos de construção e possam, enfim, vendê-los como produto final de maneira que haja um retorno satisfatório para o empreendedor. Segundo essa perspectiva, a gentrificação é o produto estrutural dos mercados fundiários e imobiliários cujo principal interesse não são as pessoas, mas a produção do capital para as áreas centrais. ${ }^{6}$

Para entender a tese da teoria integrada da gentrificação, Hamnett lista quatro requisitos necessários para que a gentrificação ocorra em uma escala significante.

1) a oferta de áreas adequadas a essa renovação;

2) a existência de gentrificadores potenciais;

3) a existência de um ambiente central economicamente desvalorizado, porém atraente;

4) a preferência cultural de certos segmentos populacionais e econômicos pela localização do centro da cidade. (Ibid.) 
Para o geógrafo César Ricardo Simoni Santos, os processos de "renovação urbana, os projetos de revitalização dos centros e a gentrificação serão as formas através das quais espaços urbanos, previamente capitalistas serão reinseridos numa nova dinâmica de acumulação". Ele ressalta que a experiência da reprodução capitalista no Brasil demorou a conhecer os processos de gentrificação como mecanismos altamente rentáveis - e que é somente na década de 1990 que a gentrificação surge como poderosa força de transformação do espaço e responde às expectativas de realização de lucros no setor imobiliário (Santos, 2011, pp. 2-39).

\section{Esse processo}

[...] envolve um novo ciclo que se remete diretamente ao espaço urbano enquanto materialidade das infraestruturas produtivas e de circulação do capital [...] Essa lógica se constitui a partir de processos de valorização-desvalorização-valorização, decorrente da construção-obsolescência-reconstrução de infraestruturas espaciais para a circulação capitalista. Na perspectiva de atrair capitais a partir de seu potencial de valorização, as cidades são reestruturadas e produzidas ("revitalizadas"). Dessa forma, vende-se a cidade, como imagem de um potencial de valorização, e é tanto maior o seu preço (e a sua procura) quanto mais real e verossímil for a sua imagem enquanto potencial de valorização. (Ibid., p. 44)

Importante notar que a gentrificação também especifica um modo de produção social do ambiente construído, levado a cabo por agentes hegemônicos. Nesse sentido, faz-se importante considerar aspectos da produção imobiliária. No contexto atual de Salvador, nota-se a presença de empresas imobiliárias, outras empresas, pessoas físicas, órgãos estatais, coletividades associadas e entidades religiosas nessa produção. Esses agentes são autorizados a efetuar a criação ou alteração no ambiente construído, de modo formalizado, através da concessão do direito de construir pela prefeitura. Constata-se um domínio territorial por empresas imobiliárias, que concentram controle jurídico de propriedade e poder de despesa monetária para financiamento dessa produção. Esse domínio contrasta com desempenhos pífios, comparativamente dos órgãos estatais, coletividades associadas e entidades religiosas (Figueiredo, 2011).

\section{Cluster Santa Tereza}

O Cluster Santa Tereza é um projeto concebido pela iniciativa privada. Em 2007, duas empresas do mercado imobiliário, as empresas Eurofort Patrimonial e RFM Participações delimitaram no Centro Antigo de Salvador uma área de 15 hectares em um tecido urbano edificado, inserido parcialmente na poligonal declarada pela Unesco, em 1985, como Patrimônio da Humanidade. Os investidores privados já adquiriram, nos últimos anos, no Bairro 2 de Julho e em uma pequena porção no bairro do Comércio, cerca de cinquenta imóveis entre terrenos, ruínas e casarões para serem transformados em lofts, pousadas, hotéis, lojas, restaurantes e escritórios. Destacam-se, dentre eles, os empreendimentos residenciais de alto luxo que estão sendo comercializados, o Cloc Marina Residence e o Trapiche Residence Adelaide, além de um 
Figura 1 - O Cluster Santa Tereza

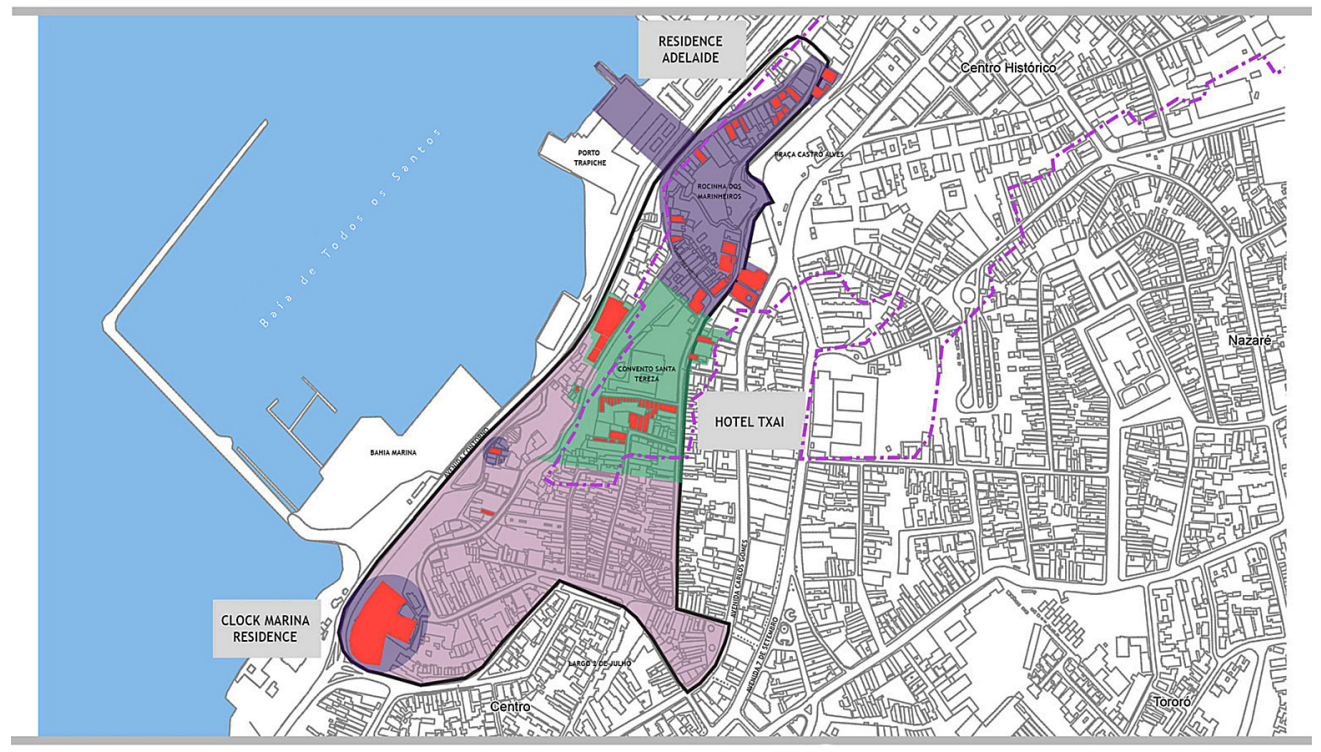

ETAPAS DE INTERVENÇÃO DO CLUSTER SANTA TEREZA
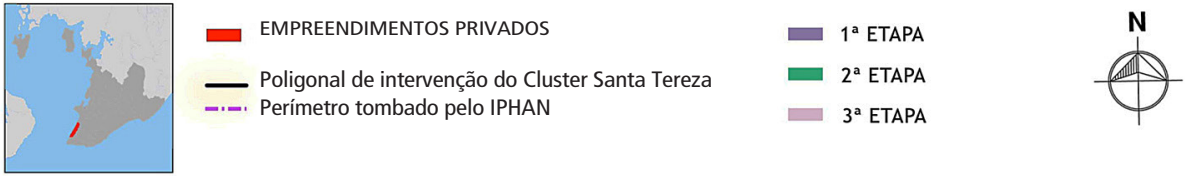

Fonte: Mourad (2011).

Resort da Rede TXAI anunciado inicialmente como "o investimento âncora, que irá promover o condomínio residencial Santa Tereza"7 _ todos explorando a vista da Baía de Todos os Santos (Mourad, 2011, p. 8).

De maneira planejada e mais sofisticada, os empreendedores do cluster escolheram e delimitaram uma área com vários elementos de valor simbólico para a população: o Museu de Arte Sacra, o Clube Carnavalesco Fantoches da Euterpe, a própria morfologia do espaço, a encosta com uma vista deslumbrante para a Baía de Todos os Santos, o fato de o Largo 2 de
Julho no passado encerrar o cortejo comemorativo da Independência da Bahia. Esses elementos, diferenciados do conjunto da cidade, oferecem condições para que se desenvolva um projeto de renovação voltado para a lógica da gentrificação.

Cotejando com a teoria integrada da gentrificação de Hamnett, nos parágrafos a seguir, podemos perceber nessa intervenção privada (com apoio público) concebida em tecido urbano pré-existente, que foram utilizados vários componentes no Cluster Santa Tereza que contribuem para que a gentrificação ocorra. 
Tem-se um ambiente central economicamente desvalorizado, porém atraente. A combinação de espaço desvalorizado e atraente tem sido utilizada pelos empreendedores privados como oportunidade para fazer negócios. Os investidores visualizam nos imóveis abandonados e em ruínas as condições favoráveis para obtenção de lucros (um capital construído ocioso, caracterizado pela baixa rentabilidade, significando uma desvalorização da riqueza construída, pública e privada). Além disso, a área escolhida para o desenvolvimento do projeto constitui-se em bens patrimoniais (ou histórico-culturais) que configuram um espaço urbano diferenciado (tombado pela Unesco como Patrimônio Mundial da Humanidade) em relação ao conjunto da cidade, com capital simbólico distintivo, com reconhecimento local, regional, nacional e internacional. Os atributos histórico-culturais do Centro Antigo e da Baía de Todos os Santos são assim mobilizados para a construção de uma imagem capaz de alavancar uma estratégia de marketing e atrair investidores (Mourad, 2011, pp. 6-151).

0 projeto foi divulgado na imprensa em 2007 como um elemento transformador do bairro: "Sodré e as ladeiras vizinhas, que correspondem às chamadas adjacências do Largo 2 de Julho, vão mudar. Em cinco anos, as casas mal conservadas ou abandonadas irão compor um centro de lazer e comércio especialmente concebido para baianos e turistas frequentarem" . ${ }^{8}$ Naquele momento, o representante da Eurofort Patrimonial anunciou que participavam do projeto investidores nacionais e estrangeiros, que se propunham a provocar uma revitalização imediata e radical na área. ${ }^{9}$

Para atrair o público seleto, os empreendedores elegeram inicialmente, em 2007, o Museu de Arte Sacra, instalado no antigo Convento de Santa Tereza d'Ávila, concluído em 1685. No entorno do Museu, uma Vila com quatorze casas pequenas pertencentes à Arquidiocese de Salvador foram vendidas, ainda que estivessem habitadas. É incorporando essa Vila e outros imóveis da rua Areal de Cima e da Avenida Contorno que a empresa Invest Tur Brasil - Desenvolvimento Imobiliário e Turístico S.A., com investimentos em grande parte do território nacional, iniciou sua atuação e divulgação do hotel de luxo da grife TXAI no Cluster Santa Tereza.

0 projeto "TXAI Salvador Hotel \& Residence", segundo divulgação da Invest Tur englobará, além do hotel, duas unidades imobiliárias, o TXAI Residence e o TXAI Exclusive. 0 hotel, com 5 mil metros quadrados de terreno, deverá contar também com o suporte de um restaurante, para atendimento aos hóspedes e a outros consumidores.

Segundo Ana Mota, representante do grupo Invest Tur, "esses empreendimentos estarão localizados no Largo 2 de Julho, entre a Av. Lafayete Coutinho e a Rua Visconde Mauá, próximo à Contorno, com vista para a Baía de Todos os Santos". Além da ambiência propiciada pela Baía, a escolha locacional deveu-se, como afirma Ana Mota, "ao valor histórico do bairro, e ao seu dinamismo, com um intenso movimento diário, diurno e noturno". Para José Romeu Ferraz Neto, copresidente da Invest Tur, essa região tende a se tornar uma das áreas mais nobres de Salvador. (Queiroz, 2009, p. 112)

Inserido no Cluster Santa Tereza, em abril de 2009, o grupo espanhol Nova Dimensão, associado à construtora Garcez, lança o empreendimento Cloc Marina Residence, contíguo a 
Vila Coração de Maria, na rua Democrata. 0 empreendimento de luxo vem atraindo estrangeiros e a população de alto poder aquisitivo. Seu caráter seletivo é facilmente percebido pelo valor do apartamento e pela sua forma de aquisição. "Os três edifícios: Casarões, Muxarabis e Jardins, que compõem o projeto, com 128 unidades residencias tipo loft, quarto e sala e duplex, estão sendo construídos pelo Regime de Administração Direta. 0 valor de um apartamento com $57,90 \mathrm{~m}^{2}$ é de $\mathrm{R} \$ 457.752,83$, sendo $R \$ 229.224,92$ o custo da fração ideal e $\mathrm{R} \$ 228.527,83$ o valor da construção" ${ }^{10}$

0 levantamento realizado, junto à Secretaria da Fazenda Municipal de Salvador (Sefaz), sobre transações de transferência de titularidade mostra que os quatorze imóveis que configuravam a Vila limítrofe ao Museu de Arte Sacra, foram adquiridos no valor de $\mathrm{R} \$ 5.000,00$ em julho de 2007, comercializados em agosto de 2007 por $\mathrm{R} \$ 17.000,00$ e após um ano revendidos para a Invest Tur por $\mathrm{R} \$ 114.000,00$ (cada um). Além da Vila, outros imóveis foram adquiridos para compor o Hotel TXAl: por exemplo, um imóvel localizado na Rua Areal de Cima, de 357 m²$^{2}$ adquirido em 10/11/2006 por $\mathrm{R} \$ 150.000,00$ foi revendido depois de dois anos por $\mathrm{R} \$ 1.606 .000,00$.

A Travessa Aquino Gaspar, onde está previsto um dos empreendimentos do Hotel TXAI, é um exemplo emblemático. Constatamos, através de pesquisa realizada junto à Sefaz que, nessa travessa de aproximadamente 50 metros, onde havia um cortiço com 14 casas, foram realizadas três comercializações do mesmo imóvel no período de três anos. $\mathrm{Na}$ Rua Areal de Cima, dentre 87 imóveis comercializados, 26\% também foram comercializados três vezes.
Os dados reunidos através de escritura de compra e venda mostram que o terreno de 4.759,17 $\mathrm{m}^{2}$ onde está sendo construído o empreendimento Cloc Marina foi vendido em 2001, no valor de $\mathrm{R} \$ 380.000,00$ e, em 2007, a CJ Construtora e Incorporadora Ltda. (pertencente a Garcez Engenharia) o adquiriu pelo valor de $\mathrm{R} \$ 6.000 .000,00$, ou seja, o processo de valorização foi de 15,8 vezes em cinco anos de intervalo. Em 2009, a CJ Construtora e Incorporadora Ltda. cedeu $70 \%$ dos direitos que detinha sobre o imóvel para empresa espanhola Nueva Dimension y Desarollo Inmobiliário SL, formando uma parceria internacional para viabilizar o empreendimento.

Dentre os 612 imóveis comercializados no período de 10 anos, 596 (97\%) foram adquiridos através de compra e venda sem mobilizar qualquer tipo de financiamento. Essa informação já indica um perfil de compradores de elevado poder aquisitivo.

Isso pode ser explicado pelo perfil dos investidores. A empresa Invest Tur Brasil - Desenvolvimento Imobiliário Turístico S. A., após quatro meses de sua fundação, realizou, em julho de 2007, uma Oferta Pública inicial de Ações (OPA) na BM\&F Bovespa, sendo a quarta maior oferta do setor imobiliário do país, em que foram captados $\mathrm{R} \$ 945$ milhões em recursos brutos. "A terceira maior empresa de hotéis do país, a Latin America Hotels (LA hotels), associou-se em fevereiro de 2009 à Invest Tur Brasil. Com um acordo firmado com a Golden Tulip Hospitality Group, a rede tornou-se responsável pela marca Golden Tulip na América do Sul".11

Depois de uma estratégia bem-sucedida de valorização da área, os imóveis adquiridos para implantar o Hotel TXAI Salvador 
pertencem agora à Brazil Hospitality Group BHG, nova marca, resultado da fusão celebrada em janeiro de 2010 entre a Invest Tur e a Latin America Hotels. 0 processo de união entre as duas empresas consolidou e explicitou, segundo "o presidente da BHG, Pieter Jacobus F. Van Voorst Vader, o foco no mercado de: hotelaria, resort superexclusivo, e a segunda residência". ${ }^{12}$

0 representante da empresa Eurofort Patrimonial, Armando Ribeiro, aproveitando (na avaliação dele) o momento em que o capital, inclusive o estrangeiro, volta-se para a Baía de Todos os Santos, lançou em dezembro de 2009, o Trapiche Residence Adelaide - pioneiro entre os empreendimentos de requinte na região.

0 restaurante Trapiche Adelaide dará lugar a um empreendimento imobiliário, que deve esquentar o mercado de Salvador, principalmente com todo o projeto de revitalização do bairro. 0 empreendimento, batizado de Residencial Adelaide em homenagem ao restaurante, abrigará 20 residências com áreas que variam de

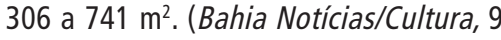
de agosto de 2009)

0 empreendimento conta com uma lista de indicadores para atrair um público de alta renda: vista para Baía de Todos Santos, bóias de atracação para cada apartamento, piscina com raias de natação e borda infinita, deck com acesso ao mar, lounge de festas, academia, lobby de entrada, spa, vagas para visitantes, sala para marinheiros e motoristas, completa infraestrutura com itens exclusivos de conforto. ${ }^{13}$

De acordo com o diretor da Imobiliária Brito \& Amoedo, Gustavo Brito,
[...] o preço do metro quadrado naquela área de borda marítima fica entre $R \$ 8$ mil e $\mathrm{R} \$ 10$ mil. Pelo menos, esses são os valores praticados no vizinho Porto Trapiche, comercializado pela Brito \& Amoedo. Essa oscilação é a mesma dos prédios com teleférico e píer na Vitória. Em relação ao Trapiche, eu não acredito que vá ser diferente, afirmou Brito. "Não é só vista para o mar. É um terreno sobre o mar. E isso não tem preço em qualquer lugar do mundo". 14

No Cluster Santa Tereza, as características do processo de gentrificação podem ser percebidas através dos empreendimentos residenciais de luxo, que já estão sendo comercializados: o Cloc Marina Residence com 57,90 $\mathrm{m}^{2}$ (um dormitório), no valor de $\mathrm{R} \$ 457.752,83$ e o Residence Adelaide com 304,00 $\mathrm{m}^{2}$ no valor de $\mathrm{R} \$ 2.617 .563,67 . .^{15} 0$ valor do imóvel evidencia o tipo de usuário que o projeto pretende atrair, bem distante dos segmentos de baixa renda que demandam moradia. Ao mesmo tempo em que são utilizados os atributos históricos e a vista diferenciada para a Baía de Todos os Santos, vários imóveis desvalorizados em ruínas ou degradados estão sendo adquiridos e funcionam como objeto do capital especulativo.

Diferente da perspectiva de recuperação da mais-valia urbana, legitimada pelas diretrizes e instrumentos do Estatuto da Cidade, constata-se uma ação de produção de valorização fundiária e imobiliária por esses empreendedores, dos quais o Município não exige nenhuma contrapartida para o bairro e para a cidade. Pelo contrário, constituem-se operações realizadas na perspectiva de transformar os imóveis e porções do território do 2 de Julho em áreas adequadas ao processo de 
gentrificação, através de processos de valorização imobiliária e da substituição da população pobre.

0 processo de expulsão da população mais pobre não se restringe às famílias que moravam na área onde será construído o Hotel TXAI. Os empreendedores do Cloc Marina Residence estão apresentando proposta de aquisição aos proprietários de imóveis localizados no entorno do empreendimento. Além disso, ao longo desse processo houve tentativa de despejo pelos proprietários de imóveis ocupados por inquilinos de baixa e média rendas. Exemplo emblemático é a ameaça de despejo sofrida pelos moradores da Vila Coração de Maria, situada na rua Democrata.

A Irmandade São Pedro dos Clérigos, proprietária dos imóveis da Vila tem ameaçado as sete famílias moradoras - incluindo a senhora Anita Ferreira Sales, de 84 anos, inquilina que assume a conservação do imóvel há 43 anos com uma ação de reintegração de posse. A Vila Coração de Maria está numa posição estratégica, contígua ao empreendimento Cloc Marina Residence, que integra a proposta do Cluster Santa Tereza.

De modo recorrente, estes empreendimentos são viabilizados, por meio da aprovação e licenciamento pela Prefeitura Municipal de Salvador, ao mesmo tempo em que são desconsideradas as demandas dos moradores e usuários do Bairro 2 de Julho. Exemplo grave refere-se ao Colégio Permínio Leite, de ensino fundamental, situado na rua Democrata, que atende as crianças de famílias pobres do 2 de Julho, Gamboa e outras localidades do entorno. Esse colégio tem suas atividades ameaçadas pelo impacto causado pela construção do empreendimento Cloc Marina Residence, contíguo ao mesmo. A desativação da escola, em último caso, implicaria que a prefeitura destinasse a apropriação desse espaço exclusivamente para o turismo de luxo, em detrimento da oferta de serviços essenciais como a educação básica da população local.

A ambiência instaurada pela ação dos agentes gentrificadores estimula também um aumento do preço dos aluguéis pelos rentistas proprietários de imóveis no bairro. Esses buscam ampliar o auferimento de renda imobiliária, substituindo os atuais inquilinos, majoritariamente de baixa renda, ${ }^{16}$ por outros de segmentos de alta renda. Com relação a esse aspecto, ressalta-se que do total estimado de 2.002 domicílios particulares permanentes no bairro, ${ }^{17}$ os domicílios alugados compreendem quase a metade do universo $(48,50 \%)$, acima inclusive da presença de domicílios próprios (47,5\%).

\section{0 privado no lugar do público: o Plano de bairro e o Projeto de Renovação do Bairro Santa Tereza da Prefeitura}

Em 2008, a prefeitura elaborou um plano do bairro denominado Santa Tereza, abrangendo parte significativa do bairro 2 de Julho. Esse plano previa ações de reurbanização de encosta e logradouros públicos, relocação de ambulantes, implantação de espaços de convivência, mobiliário urbano e estacionamentos, qualificação do sistema viário, da acessibilidade, do transporte e da iluminação pública. A prefeitura justifica seu interesse no desenvolvimento do turismo, na dinamização do 
comércio, revelando a intenção de reorganizar a mobilidade e ordenar os espaços públicos. No entanto, não houve nenhum debate com os moradores, comerciantes e frequentadores do bairro, tampouco a adoção de instrumentos de proteção e inclusão socioespacial das populações vulneráveis e de medidas para inibir a especulação imobiliária (Mourad, 2011).

Em 2012, a prefeitura lança na Associação Comercial da Bahia o Projeto de Renovação do Bairro Santa Tereza. A poligonal que demarca o projeto da prefeitura coincide, não por acaso, com a do Cluster Santa Tereza. Esse fato coloca indícios claros de que o poder público municipal estaria assumindo intervenções de urbanização para viabilizar a privatização do espaço pelas empresas que formam o cluster. Nesse projeto, novamente, o Município não estabelece nenhuma contrapartida pública, voltada aos moradores e usuários do bairro, nem aplica os instrumentos do Estatuto da Cidade que poderiam induzir a melhoria do bairro, o desenvolvimento social e econômico e especialmente resguardar a permanência dos moradores, dos comerciantes formais e informais e das atividades tradicionais do bairro (Mourad e Figueiredo, 2012).

\section{Lutas e Movimentos de contraposição}

Diante dos impactos relacionados aos processos de gentrificação mencionados, moradores, usuários, coletivos, entidades comunitárias e movimentos sociais, atuantes no Bairro 2 de Julho estão reagindo. Foi constituída uma articulação que tem empreendido diversas ações coletivas, denominada "Movimento Nosso Bairro é 2 de Julho!". Por essa articulação têm sido agenciados eventos e ações, como reuniões; assembleias de moradores, exibição de filmes, seguidos de debates e atividades artísticas no Coreto do Largo 2 de Julho; manifestações políticas de rua, como a ocorrida no último Desfile cívico do dia 2 de Julho; criação de fórum virtual de debate na internet, em página do Movimento; produção de vídeos; audiências com órgãos públicos, como a realizada no dia 12 de Julho de 2012 na Câmara de Vereadores pela Subcomissão Especial de Desenvolvimento Urbano da Assembleia Legislativa do Estado, em conjunto com a Comissão de Reparação da Câmara; visita ao bairro com a presença do Relator Nacional do Direito Humano à Cidade da Plataforma Brasileira de Direitos Humanos Econômicos, Sociais, Culturais e Ambientais DHESCA, Leandro Franklin Gorsdorf.

Em todos esses eventos e ações a falta de participação dos moradores na elaboração e implementação de planos, programas e projetos no Bairro 2 de Julho tem sido duramente criticada. Para Wlamyra Albuquerque, historiadora e moradora do bairro

A requalificação e a humanização, como têm sido propostas, vão implicar um processo de exclusão deliberada a favor de investimentos privados de alto padrão da rede hoteleira. 0 projeto mais parece uma peça publicitária de empreendimentos imobiliários de condomínios fechados, criando fronteiras sociais na cidade e áreas privadas dentro de bairros, impondo outra forma de viver [...] o projeto não representa os interesses dos moradores, que não desejam morar em lugares segregados por muros. Os moradores não querem ser coadjuvantes, convidados a assistirem o projeto de uma Prefeitura que 
atua como se comercializasse uma fração da cidade, vendendo um projeto imobiliário. Os moradores querem um projeto que dê conta das questões e problemas sociais. (Alba, 2012, p. 10)

A moradora Ivana Chastinet destaca, sobre o Projeto de Renovação do Bairro Santa Tereza que:

- Não houve consulta ou diálogo com os moradores nem usuários do Bairro 2 de Julho na elaboração do projeto;

- Não foi realizado Estudo de Impacto de Vizinhança (EIV);

- Ausência de uma pesquisa socioeconômica;

- O projeto não dialoga com os princípios introduzidos no Estatuto da Cidade.

- Ausência de definição de Zonas Especiais de Interesse Social (ZEIS),

- 0 projeto não faz qualquer menção às demandas e necessidades dos moradores e usuários do Bairro 2 de Julho. (Ibid.)

\section{0 domínio das empresas imobiliárias na produção licenciada pela prefeitura}

De forma autoritária e mudando de estratégia, a prefeitura decide encerar o debate sobre o Projeto de Renovação do Bairro Santa Tereza. ${ }^{18}$ No entanto, os processos de gentrificação continuam no Bairro 2 de Julho. A saída deliberada da prefeitura da área intensifica a ação das empresas na maximização dos ganhos, por meio de operações especulativas.

Agrava esse cenário o fato de que, a despeito do anúncio da "desistência" do projeto em questão, a prefeitura continue a licenciar e aprovar a produção de empreendimentos privados, sem critérios urbanísticos adequados, com risco de transformar as características, perfil da população e usos da área. De acordo com os dados da Tabela 1, de 2001 a 2013 foram aprovados 50 empreendimentos no Bairro 2 de Julho e entorno, correspondentes a um total de 201.443,28 $\mathrm{m}^{2}$ de área construída licenciada. ${ }^{19}$

A Figura 2 expressa um desequilíbrio nas tendências da produção imobiliária licenciada pela prefeitura de Salvador. As empresas imobiliárias assumem a dianteira da iniciativa dessa produção, respondendo por $48,7 \%$ do total de área construída licenciada no Bairro 2 de Julho, no período de 2001 a 2013. As outras empresas também têm atuação expressiva, sendo responsáveis por $39,3 \%$ desse total. Os agentes estatais, considerados conjuntamente os órgãos da União, Estado e Município, respondem por apenas $5,4 \%$ do montante de área considerado. 0 menor peso cabe ao segmento associações e cooperativas, que representa $0,3 \%$ do total em questão.

A distribuição acima indica um domínio das empresas imobiliárias, associado ao uso mercantil do espaço, dada a natureza desses agentes (Abramo, 2007). Esse fato restringe 0 acesso e a inclusão dos segmentos de baixa renda e vulneráveis aos novos empreendimentos, já que esses são direcionados a um público de alta renda, a exemplo do Cloc Marina Residence e do Residence Adelaide.

Por outro lado, a baixa presença dos empreendimentos licenciados para órgãos estatais e associações sinaliza para uma reduzida apropriação pública e coletiva da capacidade de suporte do ambiente e das redes públicas de infraestrutura novas ou existentes na área. 
Tabela 1 - Produção imobiliária licenciada no Bairro 2 de Julho por grupo de agentes - 2001 a 2013

\begin{tabular}{l|c|c|c}
\hline \multicolumn{1}{c|}{ Agentes } & $\begin{array}{c}\mathbf{N}^{\mathbf{0}} \text { de empreendimentos } \\
\text { aprovados }\end{array}$ & $\begin{array}{c}\text { Área do terreno } \\
\left(\mathbf{m}^{2}\right)\end{array}$ & $\begin{array}{c}\text { Área construída licenciada } \\
\left(\mathbf{m}^{2}\right)\end{array}$ \\
\hline Empresas imobiliárias & 9 & $52.007,81$ & $98.037,95$ \\
Outras empresas & 12 & $34.113,89$ & $79.074,78$ \\
Pessoas físicas & 24 & $8.246,48$ & $12.797,16$ \\
Município & 1 & $3.007,05$ & $8.170,83$ \\
União & 1 & 782,75 & $1.429,32$ \\
Estado & 2 & 710,04 & $1.315,92$ \\
Ass. / Coop. & 1 & 626,49 & 617,32 \\
\hline Total geral & 50 & $99.494,51$ & $201.443,28$ \\
\hline
\end{tabular}

Fonte: Elaborado por Figueiredo, com base em Sucom (2013).

Figura 2 - \% Produção imobiliária licenciada no Bairro 2 de Julho por grupo de agentes - 2001 a 2013

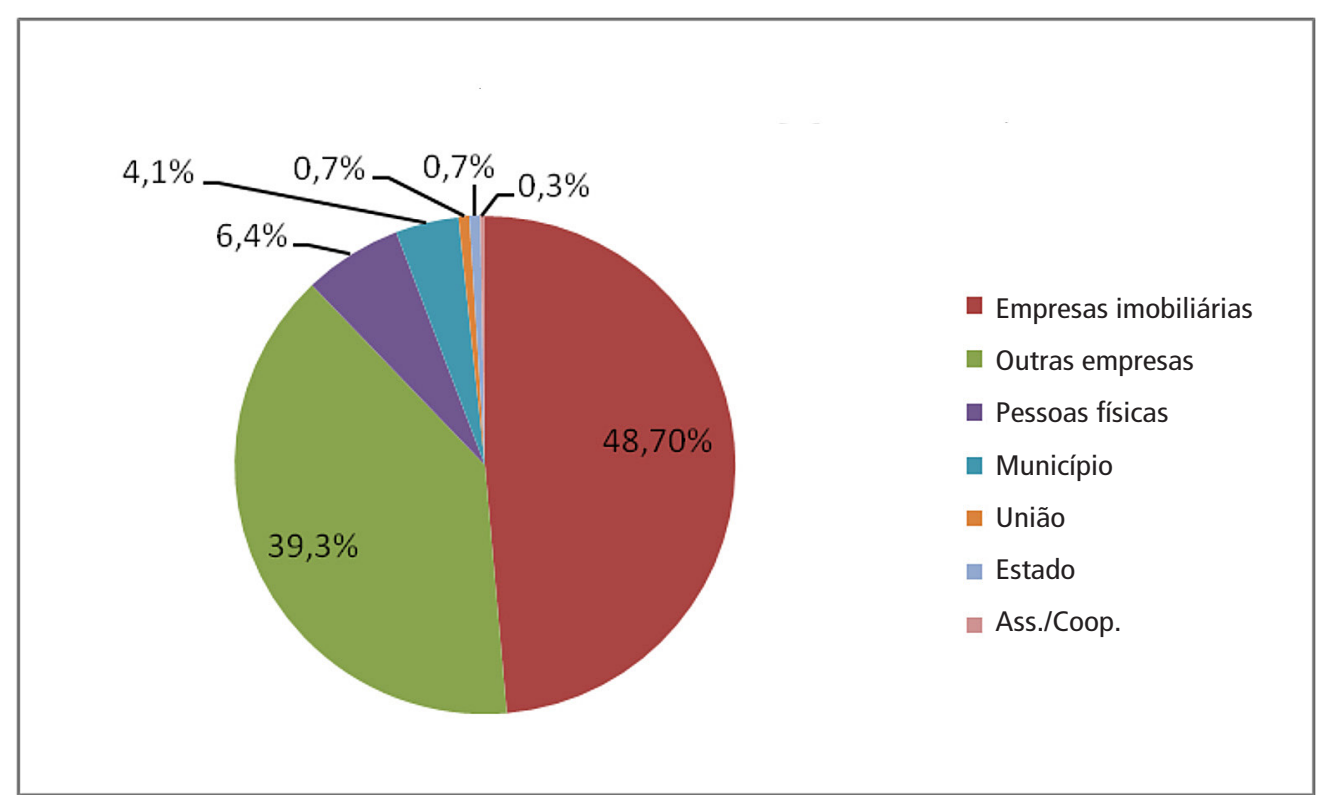

Fonte: Elaborado por Figueiredo, com base em Sucom (2013). 
Cotejando com as reflexões dos diversos autores e com o urbanista João Sette Whitaker Ferreira, podemos entender que os projetos privados e públicos lançados no Bairro 2 de Julho, se inserem na lógica de:

[...] uma intervenção de renovação onde o Mercado e Estado, vêm se associando cada vez mais, para promover um "urbanismo de mercado", incluindo as cidades à lógica da economia financeirizada e globalizada, incorporando, inclusive, as áreas obsoletas e abandonadas de grande interesse imobiliário. Deixa-se a regulação estatal do espaço público para dar livre curso à ação dos empreendedores privados, em grandes empreendimentos de "revitalização". Com fortes investimentos públicos, muitas vezes legitimados por algum grande projeto cultural, tais propostas de intervenção têm a marca da "gentrificação", a saber, a invariável expulsão dos moradores originais - geralmente pobres que aceitaram viver em áreas obsoletas e abandonadas - e sua substituição por moradores de um novo e mais alto perfil econômico. (Ferreira, 2010. Não paginado)

\section{Novas estratégias imobiliárias}

\author{
A pesquisa realizada estima a presença de 16 \\ empresas atuando no Bairro 2 de Julho. ${ }^{20}$ Se- \\ gundo Armando Correia Ribeiro, representante \\ da empresa Eurofort Patrimonial, o projeto do \\ Cluster Santa Tereza está sendo reestruturado e \\ será dividido em três etapas (ver Figura 1).
}

0 primeiro movimento foi o de criar uma empresa de desenvolvimento imobiliário, composta por uma arquiteta, um investidor europeu e um outro grupo daqui da Bahia, também ligado ao ramo imobiliário. A gente vai retomar o projeto Santa Tereza e vai desenvolver o projeto do bairro [...]. Iremos estudar qual é a vocação dos imóveis e a partir daí faremos todo o projeto, o estudo preliminar, a viabilidade econômica e até 0 levantamento e articulação com potenciais investidores.

[...]

A ideia é que os imóveis adquiridos pontualmente se transformem em núcleos de desenvolvimento. 0 primeiro núcleo é 0 da Conceição, ou seja, a Preguiça e a Ladeira da Conceição; o segundo núcleo localiza-se entre a Ladeira da Preguiça até a Rua Areal de Cima e o terceiro depende do desenvolvimento do projeto, entretanto já tem o empreendimento Cloc Marina Residence que contribuirá para alavancar outros investimentos na área. ${ }^{21}$

Para Diego Medeiros representante da Brazil Hospitality Group - BHG, empresa que adquiriu propriedades no Bairro 2 de Julho e detém autorização para utilização da marca TXAI nos projetos de desenvolvimento imobiliário, dentre os diversos segmentos de atuação da empresa a estratégia atual é de monetização dos terrenos. A BHG pretende monetizar seus terrenos através da venda, permuta ou de valorização com licenciamentos e/ou parcerias para financiar o crescimento da empresa. ${ }^{22}$

Essa estratégia já estava anunciada desde 2007 na forma como foi concebida a compra - deixando evidente o interesse no desenvolvimento de um projeto hoteleiro e no 
desenvolvimento imobiliário, como podemos perceber nas informações publicizadas, a área adquirida de $5.000 \mathrm{~m}^{2}$ no Bairro 2 de Julho

[...] foi contribuída para uma sociedade de propósito específico denominada TX Salvador SPE Empreendimentos Turísticos Ltda., na qual a Companhia detém 99,99\% de participação. 0 projeto prevê o desenvolvimento de um projeto hoteleiro - TXAI Hotel Salvador - e desenvolvimento imobiliário - TXAI Residence Salvador, sendo que a rentabilidade esperada está em linha com as taxas médias de retorno (TIR) descritas no Prospecto de Oferta Pública Inicial da Companhia de julho de 2007.23

A Figura 3, extraído da apresentação institucional da empresa BHG, enfatiza o aspecto do landbank.

Os dados reunidos mostram que 0 landbank ou estoque de terras da empresa BHG, no encerramento do exercício de 2012, contava com vários terrenos localizados em sete estados brasileiros, totalizando $R \$ 288,00$ milhões o valor de investimento. ${ }^{24}$

Figura 3 - Landbank: fonte adicional de capital

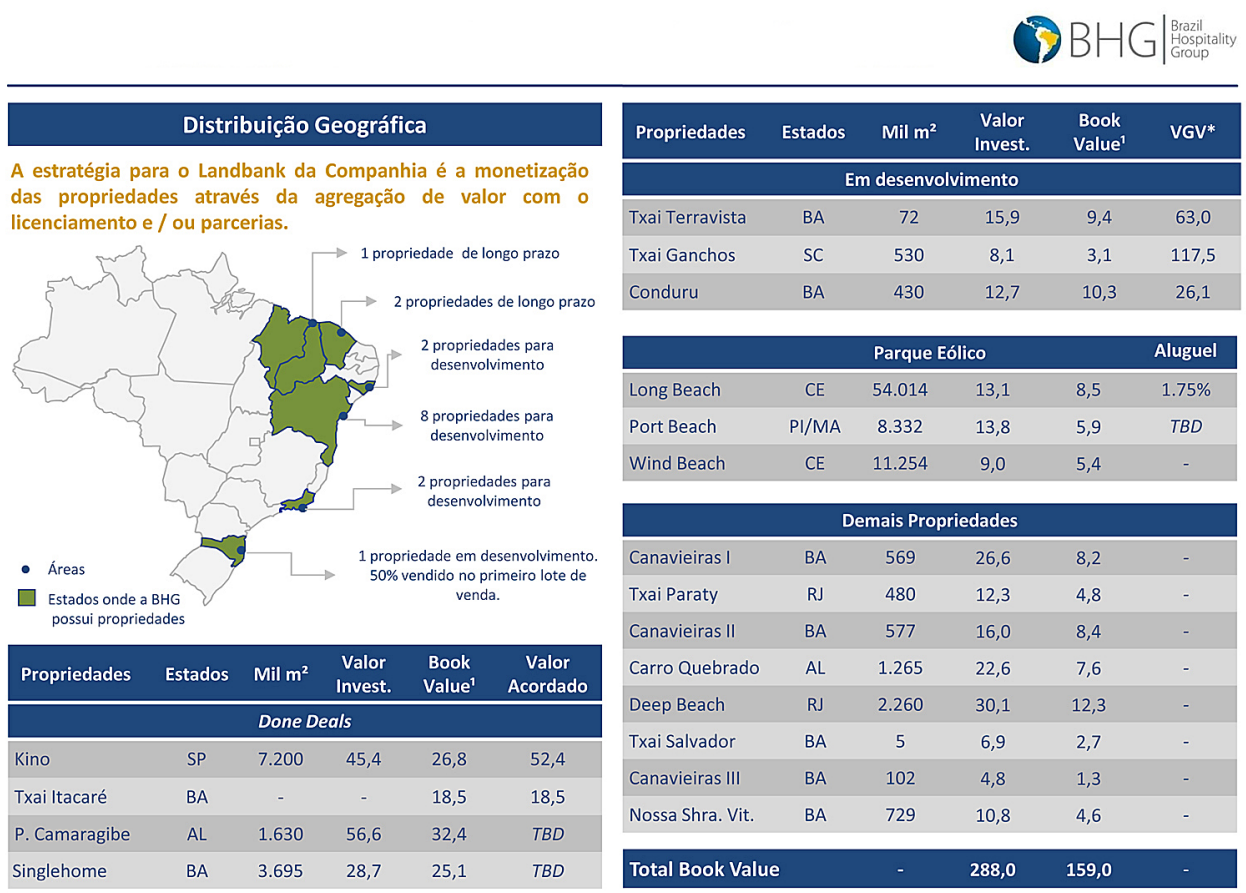

"Valores expressos em $R \$$ milhões. 'Book Value referente somente à participação da BHG.

Fonte: Brazil Hospitality Group - BHG (2013). 
As informações expressas nessa cartografia suscitam questões como: 0 que significa propriedade em desenvolvimento? Qual é a lógica de monetização das propriedades ${ }^{25}$

As novas relações estabelecidas entre o capital financeiro e o capital imobiliário indicam a existência de uma nova relação muito mais complexa que refaz as condições de acumulação do ativo terra urbana e extração da liquidez e as bases sobre as quais serão apropriadas as rendas imobiliárias (Abbreu e Vilas Boas, 2012, p. 2).

\section{Conforme analisa Mariana Fix,}

0 estoque de terrenos funciona como base para a criação de capital fictício, uma promessa de ganhos futuros antecipando o que poderá ser construído nos terrenos adquiridos. 0 monopólio sobre uma parte do território é o modo que as empresas encontram de garantir aos investidores que serão capazes de se apropriar de lucro, na construção, e de incrementos de renda da terra, na incorporação. (Fix, 2011, p. 220)

Fix, referindo-se à relação entre estoque de terrenos e circuito imobiliário, observa que

[...] a produção do meio ambiente construído dá origem a um sistema especializado e o circuito imobiliário se completa, configurando diversas frações de capital, as disputas tendem a se acirrar e a se tornarem mais complexas, promotores imobiliários assumem papel ativo em criar as condições que permitem a apropriação de renda futura. As contradições se aguçam, ainda, quando o valor de uso e de troca, o imóvel passa ser um dos lastros da valorização financeira [...] E adquire novos atributos quando 0 mercado de terras, predominante local, passa a estabelecer vínculos nas várias escalas. (Ibid., p. 238)
A propriedade da terra torna-se ativo financeiro puro, reduzindo-se a um campo de circulação do capital portador de juros. Assim, a propriedade da terra assume uma forma verdadeiramente capitalista, na qual desaparece a contradição aparente entre lei do valor e renda da terra (ibid).

Nessa condição, o imóvel passa a circular como um título e é precificado no mercado secundário. Seu preço é definido como o de qualquer ativo, pelo valor presente do rendimento futuro esperado (Fix, 2011, p. 238). No caso dos imóveis do Bairro 2 de Julho, adquiridos pela empresa $B H G$, ao invés de serem recuperados, poderão cumprir função de lastro financeiro. As relações entre o processo imobiliário e o capital financeiro passam a interagir de maneira sistêmica, gerando novos instrumentos financeiros que visam potencializar a reprodução do capital.

0 que chama nossa atenção é que a estratégia de monetização dos terrenos, de utilização do imóvel transformado em um título, ou seja, em ações, ou ainda em lastro financeiro se distancia completamente do cuidado que se deve ter com um tecido urbano de valor histórico e cultural. A ação corporativa, constatada no Bairro 2 de Julho utiliza o patrimônio histórico-cultural como fonte adicional de capital. Essa questão parece-nos central, pois estrutura uma nova forma de apropriação das rendas imobiliárias, que, contraditoriamente, aniquila os atributos que conferem singularidade a esse espaço, além de não recuperá-lo.

No Bairro 2 de Julho, essa questão pode ter repercussão mais drástica ainda, em função dos desdobramentos propostos na implantação do Plano de Reabilitação do Centro Antigo de Salvador. No âmbito desse plano, o 
Figura 4 - Mapa dos imóveis vazios e terrenos baldios

no Centro Antigo de Salvador a serem geridos

pelo Fundo de Investimento Imobiliário

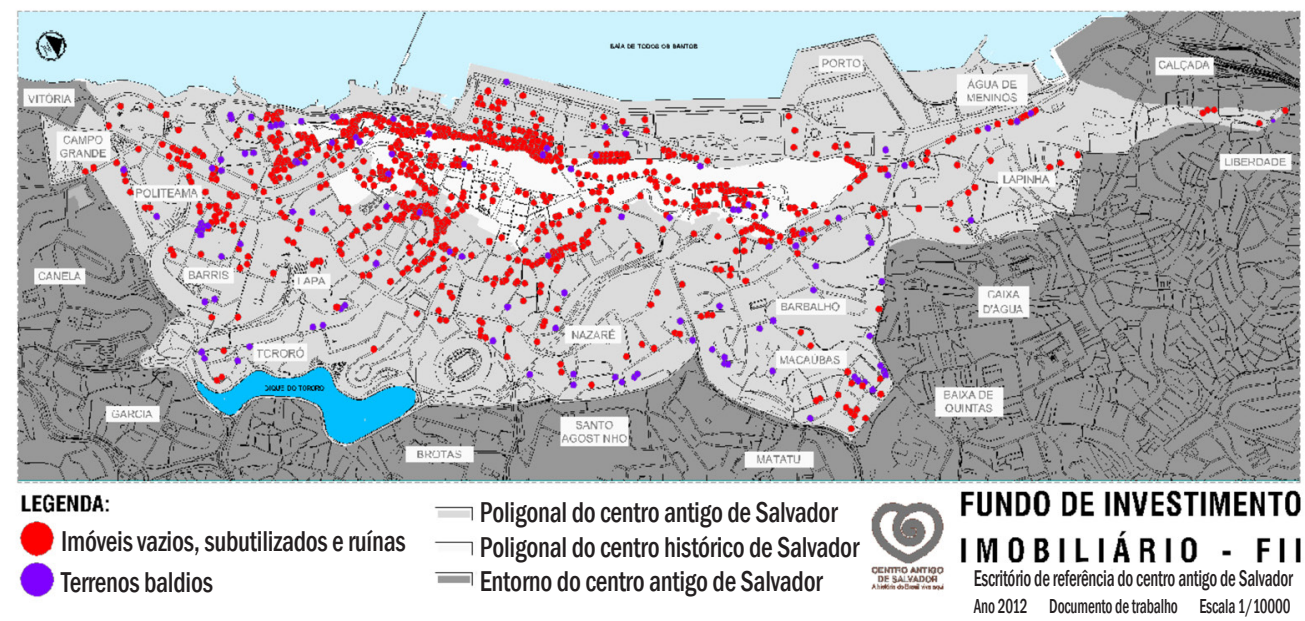

Fonte: Ercas (2012).

poder público estadual vem atualmente publicizando seu interesse em montar uma grande operação urbana calcada no instrumento da concessão urbanística. Contudo, o uso da concessão requer um amplo debate, já que a única tentativa de utilização desse instrumento, na operação Nova Luz, em São Paulo, foi suspensa na Justiça, por ameaçar os direitos humanos e promover a expulsão de populações de lugares com potencial de valorização imobiliária. $A$ concessão urbanística propõe a privatização e delegação da política de desenvolvimento urbano para a iniciativa privada, cedendo-lhes 0 poder de desapropriar imóveis residenciais e comerciais, para reformar, demolir, construir e lucrar com a revenda.

Some-se a isso, a proposta apresentada pelo Escritório de Referência do Centro Antigo de Salvador (Ercas) ${ }^{26}$ de "criação de instâncias público-privadas para a gestão/comercialização, via mercado, dos imóveis vacantes (vazios ou ociosos), com quantidade estimada em 1.500, do Centro Antigo". Isso delineia uma forma de reabilitação da área, conduzida por agentes públicos, que reforça, mais uma vez, os interesses privados (Mourad e Rebouças, 2012, p. 14).

Em Salvador, esses instrumentos são apresentados como algo de positivo e inovador. Paulo Henrique Sandroni, consultor contratado para desenvolver o estudo do Fundo de Investimento Imobiliário, sua concepção e diretrizes para a implantação de Concessão Urbanística na área do Centro Antigo de Salvador (CAS), esclarece que a proposta dessa concessão, assim como a minuta do projeto de lei do Fundo de Investimento Imobiliário, foi elaborada e debatida com o Ercas. Porém é 
exatamente nesse momento de refletir a regulamentação e de definir a forma como o instrumento vai atuar - que a sociedade não foi chamada para o debate, nesse momento tão importante, que interfere na vida dos moradores, que pode trazer modificações substantivas na composição social e/ou nas atividades econômicas - os diversos segmentos da sociedade, os moradores, os proprietários, os comerciantes formais e informais não foram chamados para debater a proposta que visa uma transformação de estrutural do CAS.

Sandroni defende a implantação de Concessão Urbanística no CAS nos seguintes termos:

Eu indiquei isto como um instrumento que poderia ser aplicado porque não há coisa mais complicada do que aquele centro de Salvador, complicada no sentido da propriedade, do endividamento, da dispersão, você não sabe nem quem são os proprietários, as sucessões de propriedade [...] Então como a Concessão Urbanística cede o direito de desapropriar os imóveis privados pelo setor privado - ela [a Concessão Urbanística] abre uma chance de você resolver isso como muito mais agilidade e rapidez. Essa é a vantagem! E a desvantagem qual é? É todo um processo de truculência que o setor privado pode usar, nessas desapropriações, especialmente contra os setores mais pobres e provocando exclusão. ${ }^{27}$

\section{Considerações finais}

0 Bairro 2 de Julho na condição de Patrimônio urbano de valor histórico e cultural não pode ser reduzido a títulos e ações de processos de monetização, nem servir como fonte adicional de capital para o mercado imobiliário. É inadmissível a produção deliberada de vazios, de obsolescência e da amplificação do estado de arruinamento do patrimônio do Centro Antigo de Salvador.

Também é equivocado o governo estadual, através do Ercas, adotar o instrumento da concessão urbanística, transformado em um instrumento de especulação imobiliária, visando à valorização do solo urbano que estabelece um processo de gentrificação oficial, formulado pelo próprio poder público (Coelho, 2010, p. 284). 0 Estado da Bahia tem justificado tal opção pelas dificuldades de solucionar as questões fundiárias e imobiliárias, porém abre mão da utilização de instrumentos de democratização do acesso à terra urbanizada e do cumprimento da função social da propriedade.

Entendemos que antes de o Estado definir o instrumento urbanístico que vai utilizar nos imóveis vacantes (ver Figura 3), ele deve abrir um amplo debate público para definir com a população, através do Plano de Bairro, como e para quem devem ser destinados os imóveis vacantes, quais os usos que deverão ser reforçados no Bairro 2 de Julho, pensado de forma equilibrada com o CAS e a cidade. Diferente disso, o governo estadual propõe oferecer ao mercado imobiliário estratégias de valorização-gentrificação do espaço, através de instrumentos como a concessão urbanística e a criação de um Fundo de Investimento Imobiliário, que serve como forma de inserção do espaço urbano nos negócios financeiros, ao dotá-lo de maior liquidez (Santos, 2008, p. 43).

Já o Município, institucionalizou uma prática de licenciamento sem critérios urbanísticos adequados e transparentes, que deixa o 
mercado agir permissivamente numa área protegida e tombada.

No que diz respeito ao movimento de contraposição aos processos de gentrificação e privatização do espaço no Bairro 2 de Julho, a sua importância está em fazer emergir articulações contra-hegemônicas, com capacidade de alterar os modos de produção e apropriação do território. Nesse sentido, fortalecer as redes comunitárias locais, que desenvolvam atividades orientadas por modos solidários de cooperação e pela autonomia associativa, mostra-se tão importante como incitar uma atuação e presença estatal reformulada a partir de uma lógica social e espacialmente inclusiva.

Diante das questões colocadas ao longo deste artigo e apesar dos inúmeros conflitos e problemas verificados, o 2 de Julho revela-se como um espaço rico de potencialidades e possibilidades para engendrar, a partir da mobilização já existente, transformações urbanas convergentes com o Direito à Cidade.

Consertar sem destruir, refazer sem desalojar, reciclar, restaurar, restituir à estima pública, criar a partir do que está dado, manter o tecido urbano o mais inalterado possível, valorizar a vida econômica, cultural e social, realizar adaptações necessárias nos equipamentos, na infraestrutura e espaços públicos, melhorar as condições de habitabilidade dos imóveis existentes, mantendo usos e a população da área. Compreender a condição de patrimônio urbano histórico-cultural do Bairro 2 de Julho como vetor de coesão e lugar social, evitando as inutilidades e o abandono dos imóveis, trazendo-os assim para reapropriação pela cidade e pelos cidadãos.

\section{Laila Mourad}

Universidade Federal da Bahia, Programa de Pós-Graduação em Arquitetura e Urbanismo, Grupo de Pesquisa Lugar Comum. Salvador/BA, Brasil.

mourad.laila7@gmail.com

\section{Glória Cecília Figueiredo}

Universidade Federal da Bahia, Programa de Pós-Graduação em Arquitetura e Urbanismo, Grupo de Pesquisa Lugar Comum. Salvador/BA, Brasil.

gloriaceciliaf@gmail.com

\section{Nelson Baltrusis}

Universidade Católica do Salvador, Programa de Pós-graduação em Planejamento Territorial. Salvador/BA, Brasil.

nbaltrusis@hotmail.com 


\section{Notas}

(1) Chris Hamnett é professor do Departamento de Geografia do King's College de Londres. Publicou em 1996, na Transactions of the Institute of British Geographres, o texto "Les aveugles et l'éléphant: l'explication da la gentrification", que trata dos processos e fatores da gentrificação. O texto foi traduzido por Catherine Rhein e Gabriel Kourchid, na revista Strates n. 9, 1996/1997.

(2) Tradução livre de Mourad. Texto original: "La gentrification est un processus de la transformation de la composition sociale des résidents d'un quartier, plus précisément la substitution de couches moyennes salariées à des couches ouvrières, et un processus de nature distincte, celui de la réhabilitation, de l'appropriation et de l'investissement, par ces couches sociales, d'un stock de logements et de quartiers ouvriers."

(3) Ruth Glass, uma socióloga inglesa, publicou o livro London: aspects of changes, em 1964. Informação apresentada por Chris Hamnett no texto Les aveugles et l'éléphant: l'explication de la gentrification, que trata dos processos e fatores da gentrificação. $O$ texto foi traduzido por Catherine Rhein e Gabriel Kourchid, na revista Strates n. 9, 1996/1997, p. 55.

(4) Entrevista ao site da editora Annablume. Disponível em: http://www.annablume.com.br/index. php?option=com_content\&view=article\&id=152: belim-barcelona\&catid=6:site. Acesso em: 10 maio 2014.

(5) O diferencial de renda é de fundamental importância para a tese de Smith. Rent gap é a diferença entre a renda potencial da terra e a renda da terra atual capitalizada nas condições presentes. Pode ser gerado pela desvalorização do capital e também pelo contínuo desenvolvimento urbano e sua expansão. A teoria do diferencial de renda (rend gap) de Smith indica que as causas originais da gentrificação estavam na mobilidade geográfica do capital e nos modelos históricos do investimento e desinvestimento no campo urbano: o investimento nas áreas periurbanas em detrimento da região central, dominante no século XX, criou condições de reinvestimentos sobre locais específicos do centro, tomando forma de gentrificação (Smith, 1979, p. 546).

(6) Tradução livre de Mourad. Texto original: "[...] Gentrification occurs when property depreciation is significant, when the gap (income differentiation) is large enough so that entrepreneurs can acquire structures at low cost, can pay the cost to build and profit from renovation, can also pay the interests on personal and construction loans and can finally sell them as final products in order to get satisfactory returns. Based on this perspective, gentrification is the structural product of land property and real estate markets, which main interest is not people but the production of capital for central areas."

(7) Informação disponível no site da Construtora Gatto (2010).

(8) Disponível no site <www.skyscrapercity.com/showthread.php?t=615255> (2010).

(9) Idem.

(10) Informações extraídas do stand de venda do empreendimento Cloc Marina Residence (Shopping Barra, na própria área onde será executado o empreendimento e junto à imobiliária Brito \& Amoedo). A Brito \& Amoedo informou que $50 \%$ dos compradores são estrangeiros e $50 \%$ são brasileiros. 
(11) Informações disponíveis no site <http://www.acionista.com.br/rx/rx_bhg_2010.html> (2010).

(12) Informações disponíveis no site <http://www.jornaldeturismo.com.br/noticias/hotelaria/30663brazil-hospitality-group-bhg-divulga-marca-no-rio.html> (2010).

(13) Informações extraídas do site <http://vender-casa-apartamento.vivastreet.com.br/comprarimovel+se/trapiche-adelaide-residencial/21393702> (2010).

(14) Informação disponível no site do jornal $A$ Tarde (2010).

(15) Os apartamentos têm de 304 a $796 \mathrm{~m}^{2}$ de área privativa e custam $\mathrm{R} \$ 8.610,40$ o metro quadrado, conforme informações disponíveis nos sites <http://www.imoveisdeluxo.com.br/anuncio. asp?ida=1514> (2012) e <http://www.andrademendonca.com/noticias/9/residencial-adelaide> (2012).

(16) Conforme dados do Censo 2010 do IBGE para os setores censitários que abrangem o Bairro 2 de Julho, essa é uma área de ocupação predominantemente de segmentos de baixa renda domiciliar, e $66,5 \%$ de seus domicílios têm renda mensal domiciliar de até três salários mínimos (IBGE, 2010).

(17) Conforme dados do Censo 2010 do IBGE para os setores censitários que abrangem o Bairro 2 de Julho (ibid.).

(18) Conforme nota publicada no dia 30 de julho no blog Bahia Notícias (Bahia Notícias, 2012).

(19) Os dados do ano de 2013 referem-se aos alvarás de construção aprovados e publicados até o mês de março.

(20) Conforme alvarás de construção emitidos pela Sucom de 2001 a 2013, sistematizados pelos autores.

(21) Entrevista realizada por Laila Mourad com Armando Correia Ribeiro, em 20 de agosto de 2010.

(22) Dados fornecidos por Diego Medeiros representante da Brazil Hospitality Group - BHG, em 6 de fevereiro de 2013.

(23) Documento "2012.14_Earnings 2T12_FINAL.pdf”, disponível no site <www.bhg.net> (2013).

(24) http://www.econoinfo.com.br/comunicados/BHG/Principais-eventos-societarios/886203476161?p=4.

(25) Apresentação institucional da empresa BHG (2013).

(26) Apresentado no evento organizado pelo Ercas, intitulado Seminário Internacional Brasil - Junta de Andalucía (Espanha): Estratégias de Reabilitação Urbana e Edilícia, Gestão, Habitação e Projeto, realizado nos dias 12 e 13 de junho de 2012, Salvador, Bahia, Brasil.

(27) Entrevista realizada pela autora com Paulo Henrique Sandroni, em 14 de fevereiro de 2013. 


\section{Referências}

ABRAMO, P. (2007). A Cidade Caleidoscópica: coordenação espacial e convenção urbana: uma perspectiva heterodoxa para a economia urbana. Rio de Janeiro, Bertrand Brasil.

ABREU, M. A. e VILAS BOAS, T. B. F. (2012). Considerações acerca das novas estratégias de atuação das grandes incorporadoras na produção do espaço urbano. Disponível em: www.eng2012.org. br. Acesso em: mar 2013.

ARANTES, O. (2000). "Uma estratégia fatal: a cultura nas novas gestões urbanas". In: ARANTES, O., VAINER, C. e MARICATO, E. A cidade do pensamento único. Desmanchando consensos. Petrópolis, Vozes.

ASSEMBLEIA LEGISLATIVA DO ESTADO DA BAHIA (ALBA) / SUBCOMISSÃO DE DESENVOLVIMENTO URBANO (2012). Relatório da Audiência Pública "Projetos no Bairro 2 de Julho: impactos e medidas de salvaguarda da população. Salvador.

BAHIA NOTÍCIAS (2012). Prefeitura desiste do Projeto de Requalificação do 2 de Julho. Disponível em: http://bahianoticias.com.br/principal/noticia/120109-prefeitura-desiste-de-projeto-derequalificacaodo-2-de-julho.html. Acesso em: jul 2012.

BAHIA NOTÍCIAS/CULTURA (2009). Matéria publicada em agosto de 2009. Trapiche Adelaide passara por mudanças em breve. Disponível em: http://www.bahianoticias.com.br/cultura/noticia/5109trapiche-adelaide-passara-por-mudancas-em-breve.html. Acesso em: mar 2011

BRAZIL HOSPITALITY GROUP (2012). Documento 2012.14_Earnings 2T12_FINAL.pdf. Disponível em: www.bhg.net. Acesso em: fev 2013.

(2013). Apresentação institucional da empresa. Disponível em: www.mzweb.com.br/ BHG/... /download_arquivos.asp?. Acesso em: jan 2013.

COELHO JR., M. N. (2010). Processos de intervenção urbana: bairro da Luz, São Paulo. Tese de doutorado. São Paulo, Universidade de São Paulo.

CONSTRUTORAANDRADE MENDONÇA (2011). Notícias. Disponível em: http://www.andrademendonca. com/noticias/9/residencial-adelaide. Acesso em: jul 2012.

CONSTRUTORA GATTO (2010). Notícias. Disponível em: http://www.construtoragatto.com.br/ novidades/noticias/salvador-ganhara-hotel-de-luxo-da-grife-txai. Acesso em: dez 2010.

ESCRITÓRIO DE REFERÊNCIA DO CENTRO ANTIGO DE SALVADOR - ERCAS (2009). Plano de Reabilitação do Centro Antigo de Salvador: diagnóstico da economia dotTurismo no Centro Antigo de Salvador, elaborado por Lúcia Aquino Queiroz.

(2010). Plano de Reabilitação Participativo do Centro Antigo de Salvador. Salvador.

(2012). Apresentação do Seminário Internacional Brasil - Junta de Andalucía (Espanha): Estratégias de Reabilitação Urbana e Edilícia, Gestão, Habitação e Projeto. Salvador.

FERNANDES, A. (2006). Grandes projetos urbanos: o que se pode aprender com a experiência brasileira? Programa de Recuperação do Centro Histórico de Salvador (Bahia, Brasil), Ana Fernandes (coord.), PPG-AU Faculdade de Arquitetura-UFBa/ Lincoln Institute of Land Policy, Salvador.

(2008). Centro Antigo de Salvador: centralidades em disputa e desafios à ação. Infocultura. Salvador, n. 2. 
FERNANDES, A. (2013). Projeto Plano de Bairro 2 de Julho. In: PROGRAMA DE EXTENSÃO UNIVERSITÁRIA PROEXT 2013. Instituição/UFBA, MEC/SESU, 2013. (No prelo).

FERNANDES, A; MOURAD, L, N. e SILVA, H. M. B. (no prelo). "Política urbana em cidades brasileiras: gentrificando centros?" In: CONTRERAS, Y., LULLE e OSCAR FIGUEROA, T. (orgs.). Gentrificación: Un fenómeno representativo de los cambios sociales de las áreas centrales latinoamericanas? Santiago do Chile, PUC.

FIGUEIREDO, G. C. dos S. (2011). A hegemonia das empresas imobiliárias: tendências de uso e ocupação do espaço da produção imobiliária licenciada pelo município de Salvador de 2001 a 2009. Dissertação de mestrado. Salvador, Universidade Federal da Bahia.

FIX, M. de A. B. (2011). Financeirização e transformações recentes no circuito imobiliário no Brasil. Tese de doutorado. Campinas, Universidade Estadual de Campinas.

FRÚGOLI, J. H. e SKLAIR, J. (2009). O bairro da Luz em São Paulo: questões antropológicas sobre o fenômeno da gentrification. Cuadernos de Antropología Social. FFyL, Universidade de Buenos Aires, n. 30, pp. 119-136.

GLASS, R. (1963). Introduction to London: aspects of change. Londres, Center for Urban Studies.

HAMNETT, C. (1996-1997). Les aveugles et l'éléphant: l'explication de la gentrification. Strates, Matériaux pour la recherche en sciences sociales crises et mutations des territoires. In: CENTRE NATIONAL DE LA RECHERCHE SCIENTIFIQUE-CNRS, n. 9.

INSTITUTO BRASILEIRO DE GEOGRAFIA E ESTATÍSTICA (IBGE). Censo 2010. Disponível em: http://www. ibge.gov.br/home/estatistica/populacao/censo2010/. Acesso em: jan 2012.

JORNAL A TARDE. Matéria publicada em agosto de 2008. Luxo invade o pôr-do-sol. Disponível em: http://www.atarde.com.br/jornalatard....jsf?id=963404. Acesso em: jan 2010.

JOSÉ, B. K. (2007). Políticas culturais e negócios urbanos: a instrumentalização da cultura na revalorização do centro de São Paulo (1975-2000). São Paulo, Annablume/Fapesp.

MARICATO, E. (2002). Prós e contras da revitalização de centros urbanos. Disponível em: http://www. comciência.br/cidades. Acesso em: dez 2012.

MOURAD, L. N. (2011). O processo de gentrificação do centro antigo de Salvador 2000 a 2010. Tese de doutorado. Salvador, Universidade Federal da Bahia.

MOURAD, L. N. e BALTRUSIS, N. (2013). "Movimentos de resistência aos processos de renovação conservadora e excludente no centro histórico de Salvador". In: FERNANDES, J. R.; CUNHA, L. e CHAMUSCA, P. 1 o Seminário internacional do CEGOT. Geography, Politics, Policies e Planning. Porto, Portugal, Edição Faculdade de Letras/CEGOT, pp. 762-774.

MOURAD, L. N. e FIGUEIREDO, G. C. (2012). O bairro é 2 de Julho, ou, o que está em jogo no Projeto de Humanização de Santa Tereza? In: SEMINÁRIO URBANISMO NA BAHIA - URBA12. A produção da cidade e a captura do público. Que perspectivas? Salvador, Faculdade de Arquitetura da UFBA.

MOURAD, L. N. e REBOUÇAS, T. de M. (2012). Elegia aos vacantes. Considerações acerca do plano de reabilitação do centro antigo de Salvador. In: URBICENTROS\#3. III Seminário Internacional: Morte e vida dos centros urbanos. Salvador, Faculdade de Arquitetura da UFBA.

QUEIROZ, L. A. (2009). Diagnóstico da Economia do Turismo no Centro Antigo de Salvador. Subsídios para elaboração do Plano de Reabilitação do Centro Antigo de Salvador, coordenado pela Secretaria de Cultura do Estado da Bahia e Escritório de referência do Centro Antigo de Salvador/ Ercas, Salvador. 
RETTO JR, A. S. e ARANTES, O. B. F. (2013). Entrevista com Otilia Arantes. Revista Vitruvius, v. 056.02, pp. 1-8.

RIBEIRO, A. C. (2010). Entrevista realizada por Laila Nazem Mourad. Salvador, 20 de agosto.

ROLNIK, R. (2006). "Por um novo lugar para os velhos centros". In: O ESTADO DE S. PAULO/ALIÁS - A semana revista. São Paulo, p. J6-J6, 16 abr.

SANDRONI, P. H. (2013). Entrevista realizada por Laila Nazem Mourad. São Paulo, 14 de fev.

SANTOS, C. R. S. (2011). A gentrificação como atualização das estratégias imobiliárias: os novos dispositivos da acumulação. In: XIV ENCONTRO NACIONAL DA ANPUR. Anais. Rio de Janeiro.

SILVA, H. M. M. B. (2006). “Prefácio, Pósfacio/Apresentação”. In: BIDOU-ZACHARIASEN, C. De volta à cidade: dos processos de gentrificação às políticas de revitalização dos centros urbanos. São Paulo, Annablume.

SITE ACIONISTA (2010). Informações disponíveis no site. Disponível em: http://www.acionista.com.br/ rx/rx_bhg_2010.html. Acesso em: maio 2010

SITE ECONOINFO (2012). Informações disponíveis no site. Disponível em: http://www.econoinfo.com. br/comunicados/BHG/Principais-eventos-societarios/886203476161?p=4. Acesso em: jan 2013.

SITE IMOVEISDELUXO (2010). Informações disponíveis no site. Disponível em: http://www. imoveisdeluxo.com.br/anuncio.asp?ida=1514. Acesso em: maio 2010.

SITE JORNAL DE TURISMO (2009). Informações disponíveis no site. Disponível em: http://www. jornaldeturismo.com.br/noticias/hotelaria/30663-brazil-hospitality-group-bhg-divulga-marcano-rio.html. Acesso em: maio 2010.

SITE SKYSCRAPERCITY (2007). Informações disponíveis no site. Disponível em: www.skyscrapercity. com/showthread.php?t=615255. Acesso em: $\operatorname{mar} 2010$.

SITE VIVASTREET (2010). Informações disponíveis no site. Disponível em: http://vender-casaapartamento.vivastreet.com.br/comprar-imovel+se/trapiche-adelaide-residencial/21393702. Acesso em: ago 2010.

SMITH, N. (1979). Toward a theory of gentrification: a back to the city movement by capital, not people. Journal of the American Planning Association, v. 45, pp. 538-548.

(2006). “A gentrificação generalizada: de uma anomalia local à regeneração urbana como estratégia urbana global". In: BIDOU-ZACHARIASEN, C. De volta à cidade: dos processos de gentrificação às políticas de revitalização dos centros urbanos. São Paulo, Annablume.

SUPERINTENDÊNCIA DO CONTROLE E ORDENAMENTO DO USO DO SOLO DO MUNICÍPIO (SUCOM). Relação de alvarás publicados no Diário Oficial do Município. Disponível em: http://www.sucomantigo.salvador.ba.gov. br/portaldeservicos/servicos-online/servicosonline/informacoes/ consulta_alvaras_construcao_emitidos.aspx. Acesso em: mar 2013.

VAINER, C. (2002). Prós e contras da revitalização de centros urbanos. Disponível em: http://www. comciência.br/cidades. Acesso em: abr 2010.

Texto recebido em 16/out/2013

Texto aprovado em 17/abr/2014 